\title{
MODEL OF EXPERIMENTAL INFECTION IN HEALTHY AND IMMUNOSUPPRESSED SWISS ALBINO MICE (MUS MUSCULUS) USING CANDIDA ALBICANS STRAINS WITH DIFFERENT PATTERNS OF ENZYMATIC ACTIVITY
}

\author{
Guilherme M. Chaves ${ }^{1}$; Maria Auxiliadora de Q. Cavalcanti1 ${ }^{1 *}$; Ana Maria dos A. Carneiro-Leão² Silvia L. Lopes $^{3}$ \\ ${ }^{1}$ Departamento de Micologia, Centro de Ciências Biológicas, Universidade Federal de Pernambuco, Recife, PE, Brasil; \\ ${ }^{2}$ Departamento de Morfologia e Fisiologia Animal, Universidade Federal Rural de Pernambuco, Recife, PE, Brasil; \\ ${ }^{3}$ Departamento de Patologia, Centro de Ciências da Saúde, Universidade Federal de Pernambuco, Recife, PE, Brasil
}

Submitted: June 14, 2004; Approved: December 20, 2004

\begin{abstract}
With the purpose to evaluate Candida albicans virulence in vivo, two strains selected were based on their phospholipase and proteinase activity, and used in a model of experimental infection. One strain, isolated from vaginal secretion, was stocked at the URM Culture Collection for 43 years and presented high phospholipase $(\mathrm{Pz}=0.217)$ and proteinase $\left(1.386 \mathrm{U} \cdot \mathrm{mL}^{-1}\right)$ activity. The other strain was a fresh strain isolated from oropharyngeal secretion of an AIDS patient, and presented low phospholipase $(\mathrm{Pz}=0.482)$ and proteinase $\left(0.780 \mathrm{U} . \mathrm{mL}^{-1}\right)$ activity. The strains were inoculated via intraperitoneum in immunosuppressed and non-immunosuppressed mice (Mus musculus) and the infection was evaluated over a period of 21 days. Liver, spleen, lungs and kidneys were aseptically removed and the blood of the animals was collected every $72 \mathrm{~h}$. The number of colony forming units (c.f.u) isolated from each organ was counted and a histopathologic examination was performed. The freshly isolated strain was more virulent than the stocked strain, as shown by the number of positive cultures and severity of the lesions observed at the histopathologic examination. A correlation between the in vitro enzymatic activity and the in vivo virulence was not observed.
\end{abstract}

Key words: Candida albicans, extracellular enzymes, virulence, experimental infection

\section{INTRODUCTION}

Candida albicans is the most pathogenic species of a genus of yeasts that normally exists in the human microflora, but that can also cause infections. It is an opportunistic pathogen that usually lives as a commensal in the healthy human host. Alterations in the balance between the commensal and the host, such as those that occur in the immunocompromised patients may trigger infection of the mucosal epithelia, followed by dissemination via the bloodstream and colonization of internal organs $(2,13,15)$.

Several virulence factors have been proposed for C. albicans including extracellular enzymes such as phospholipases and proteinases production. Phospholipase activity has been considered an important factor for the infection process for acting on phospholipids hydrolysis, damaging epithelial cells (11). Secreted Aspartic Proteinases (SAPS) are important virulence factors during mucous or disseminated infections caused by $C$. albicans (29). Extracellular proteolytic activity enables $C$. albicans to utilise exogenous protein as the sole nitrogen source.

The aim of the present study was to evaluate the virulence of two C. albicans strains (in vivo), selected by different patterns of phospholipase and proteinase activity, through a model of experimental infection using immunosuppressed and nonimmunosuppressed mice.

*Corresponding author. Mailing address: Departamento de Micologia, Centro de Ciências Biológicas, Universidade Federal de Pernambuco, Av. Prof. Nelson Chaves, S/N, Cidade Universitária. 50670-420, Recife, PE, Brasil. Fax: (+5581) 3271-8482. E-mail: xiliamac@terra.com.br 


\section{MATERIALS AND METHODS}

\section{Microorganisms}

Two strains of $C$. albicans with high and low phospholipase and proteinase activity were selected. The first strain, isolated from vaginal secretion, was stocked at URM Culture Collection for 43 years (strain 743) and presented high phospholipase $(\mathrm{Pz}=0.217)$ and proteinase $\left(1.386 \mathrm{U} \cdot \mathrm{mL}^{-1}\right)$ activity. The second strain was freshly isolated from oropharyngeal secretion of an AIDS patient (strain 18) and presented low phospholipase $(\mathrm{Pz}=0.482)$ and proteinase $\left(0.780 \mathrm{U} \cdot \mathrm{mL}^{-1}\right)$ activity. The strains were maintained on Sabouraud agar plus yeast extract $(\mathrm{SAB}+$ YE) slants, at room temperature $\left(28+/-1^{\circ} \mathrm{C}\right)$.

\section{Animals}

Two hundred and twenty four female swiss albino mice (Mus musculus) were used. The animals were approximately 8 weeks old and weighed 25-30 g. They were housed in plastic cages and supplied water and food ad libitum. The animals were purchased from the Laboratory of Immunopathology Keizo Asami (LIKA-UFPE).

\section{Inoculum set up and inoculation}

The strains were inoculated onto slants containing SAB $+\mathrm{YE}$ and incubated at $37^{\circ} \mathrm{C}$ over a period of $48 \mathrm{~h}$. Subsequently, $5 \mathrm{~mL}$ of Tween $800.05 \% \mathrm{v} / \mathrm{v}$ in $\mathrm{NaCl} 150 \mathrm{mM}$ (saline-tween) was added to each slant. The slants were mechanically agitated with a vortex. The resultant suspension was filtered through 8 layers of sterilized gauze and subsequently centrifuged for 5 minutes at 3000 r.p.m. The cells were washed twice with saline-tween and centrifuged under the same conditions. After the washes, the number of cells was determined with a heamocytometer and the final concentration was adjusted to $5 \times 10^{6}$ cells. $\mathrm{mL}^{-1}$ and to $5 \times 10^{7}$ cells. $\mathrm{mL}^{-1}$, using $150 \mathrm{mM} \mathrm{NaCl}$. The animals were inoculated via intraperitoneum with $0.2 \mathrm{~mL}$ of the suspensions of yeast cells, as described in Table 1 .

\section{Experimental design}

Each period of experiment lasted 21 days. Eight animals were sacrificed every $72 \mathrm{~h}$ by cervical dislocation using xylazine and kitamine chlorohydrate as anesthetic (10 mg. Kg ${ }^{-1}$ and $115 \mathrm{mg}$. $\mathrm{Kg}^{-1}$, respectively). The organs (liver, spleen, lungs and kidneys) of four animals were removed and submitted to c.f.u. counts. The organs of other four animals were submitted to histopathologic examination. Each group of animals contained seven animals which were injected via intraperitoneum with saline solution and/or the immunosupressor, but were not inoculated with C. albicans cells (controls).

\section{Induction of immunosuppression}

The animals of the groups B and D ( $=112)$ (Table 1) were inoculated via intraperitoneum according to Holzschu (7),
Table 1. Distribution of albino swiss mice (Mus musculus) groups challenged with $C$. albicans.

\begin{tabular}{cccc}
\hline $\begin{array}{c}\text { Group } \\
\text { evaluated }\end{array}$ & $\begin{array}{c}\text { Strains } \\
\text { used }\end{array}$ & Inoculum & Immunosuppression \\
\hline $\mathrm{A}(\mathrm{n}=56)$ & 743 & $5 \times 10^{6} \mathrm{~mL}^{-1}$ & Negative \\
$\mathrm{B}(\mathrm{n}=56)$ & 743 & $5 \times 10^{7} \mathrm{~mL}^{-1}$ & Positive \\
$\mathrm{C}(\mathrm{n}=56)$ & 18 & $5 \times 10^{6} \mathrm{~mL}^{-1}$ & Negative \\
$\mathrm{D}(\mathrm{n}=56)$ & 18 & $5 \times 10^{7} \mathrm{~mL}^{-1}$ & Positive \\
\hline
\end{tabular}

substituting the cortisone acetate for $10 \mathrm{mg} \cdot \mathrm{mL}^{-1}$ of hydrocortisone succinate (solu-cortef, Rhodia $\left.{ }^{\circledR}\right)$. Each animal received $0.1 \mathrm{~mL}$ of hydrocortisone succinate suspended in saline solution for 3 days before and 5 days after $C$. albicans inoculation.

\section{Quantification of the c.f.u. in the organs}

At every $72 \mathrm{~h}$ after inoculation, the organs (liver, spleen, lungs and kidneys) were aseptically removed and homogenized with a tissue homogenizer (Tokio, Japan ${ }^{\circledR}$ ) using $5 \mathrm{~mL}$ of salinetween. The blood $(100 \mu \mathrm{l})$ was collected from the heart and transferred to sterilized ependorff tubes containing heparin $10 \% \mathrm{v} / \mathrm{v}$. The tissue suspensions and the blood samples were transferred to Petri dishes containing SAB + YE + chloramphenicol and maintained at room temperature for $48 \mathrm{~h}$. The colonies were counted and the number of c.f.u. per organ and per $100 \mu \mathrm{l}$ of blood was determined. One isolated colony from each organ was transferred to SAB + YE slant, and submitted to biochemical and physiological tests to confirm if the colony recovered was C. albicans $(3,12,16)$.

\section{Histopathologic examination}

Histopathologic examinations were performed every $72 \mathrm{~h}$ after the challenge of the animals. The organs were submitted to a perfusion with saline solution and to the routine histology process (20). The organs were fixed in formaldehyde $(4.0 \% \mathrm{v} / \mathrm{v}$, prepared in PBS 0.01 M, pH 7.2) for 7 days, dehydrated in ethanol at concentrations of $70 \%, 80 \%, 90 \%$ and $100 \% \mathrm{v} / \mathrm{v}$; diaphanized with xylol and embedded in paraffin. After microtomy $(4 \mu \mathrm{m})$, the sections were stained with hematoxylin-eosin.

\section{Statistical analysis}

The results obtained were expressed as mean \pm standard deviation $(\mathrm{M} \pm \mathrm{SD})$ and submitted to Variance Analysis and Tukey's test, using significance level of $\mathrm{p} \leq 0.05$ (1).

\section{RESULTS}

\section{Quantification of c.f.u. in the organs}

Positive cultures were recovered from the liver of the animals belonging to the groups B (strain 743, immunosuppression 
positive), $\mathrm{C}$ (strain 18, immunosuppression negative) and $\mathrm{D}$ (strain 18, immunosuppression positive). In group $\mathrm{B}$, positive cultures were obtained over a period of 3 to 15 days of infection, and the numbers of c.f.u. did not show a statistically significant variation over this period. In group $\mathrm{C}$, positive cultures were obtained from the $3^{\text {rd }}$ to the $12^{\text {th }}$ day and the number of c.f.u. in this group also did not show a statistically significant variation. Regarding to the group D, the days 3, 6, 9 and 12 showed remarkably high number of c.f.u. (numbers statistically the same) which decreased on days 15,18 and 21 . The numbers of c.f.u. on days 15 and 21 were statistically the same, but different from those on day 18 (Fig. 1).

In the spleen, positive cultures were obtained from the groups B (strain 743 immunosuppression positive), C (strain 18 immunosuppression negative) and D (strain 18 immunosuppression positive). In group $\mathrm{B}$, the variation of the c.f.u. number over the studied period was not statistically significant. In group C, only one positive culture was obtained (6 c.f.u.). However, this result was not considered statistically significant. Regarding to the group D, on the days 3, 6, 9 and 12, it was verified that the high numbers of c.f.u. were the same and different from those obtained on days 15, 18 and 21, when there was a remarkable decrease in the numbers of c.f.u. (Fig. 2).

In the lungs, positive cultures were observed in groups B (strain 743, immunosuppression positive) and D (strain 18, immunosuppression positive). In group $\mathrm{B}$, only one positive culture was obtained, which was not considered statistically significant. In group D, the numbers of c.f.u. on the days 3 and 6 were statistically the same. Results on these two days were statistically different of those on days $9,12,15,18$ and 21, which presented the same number of c.f.u. (Fig. 3).

\section{Liver}

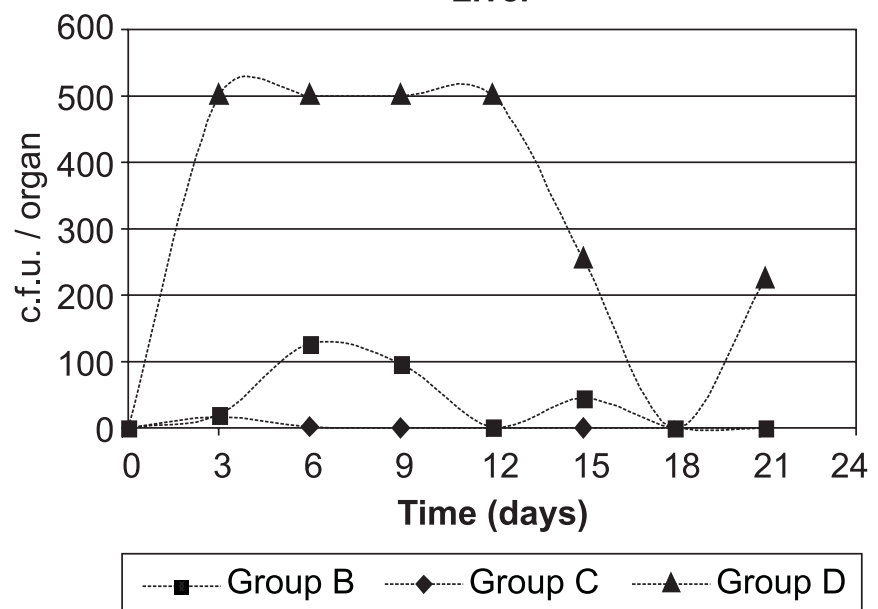

Figure 1. Variation in c.f.u. counts of $C$. albicans recovered from the liver of swiss albino mice (M. musculus) over the period of experimental infection.
Regarding to the kidneys, positive cultures were verified in groups A (strain 743 immunosuppression negative), C (strain 18 immunosuppression negative), and D (strain 18 immunosuppression positive). Group A presented only one c.f.u. on day 15 , while group $\mathrm{C}$ presented only one c.f.u. on days 3 and 6 . These numbers were not considered statistically significant. In group D, the counts on days 3, 6, 9, 12 and 21 were the same and statistically different from those on the days 15 and e 18 . The counts on day 15 were statistically different of those on days 18 and 21 (Fig. 4).

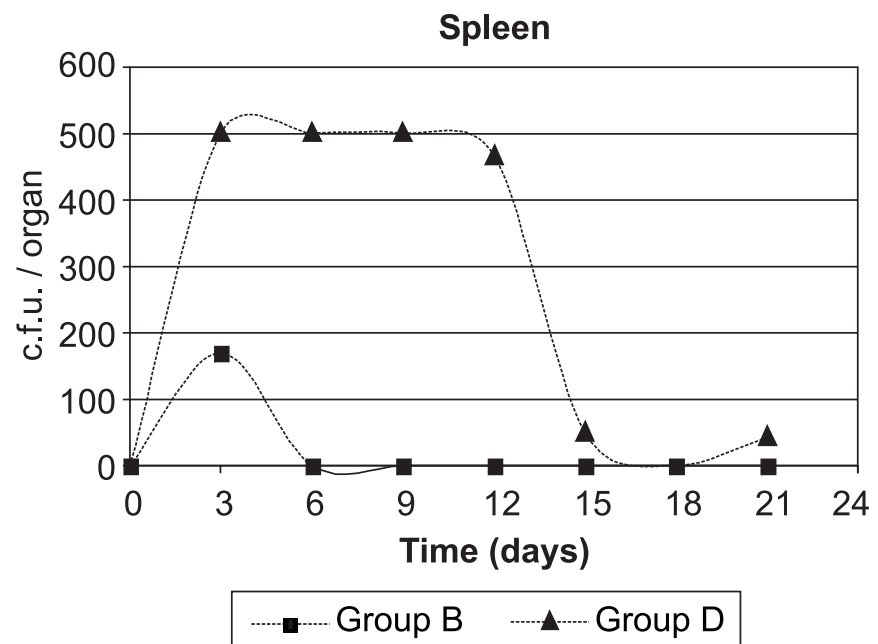

Figure 2. Variation in c.f.u. counts of $C$. albicans recovered from the spleen of swiss albino mice (M. musculus) over the period of experimental infection.

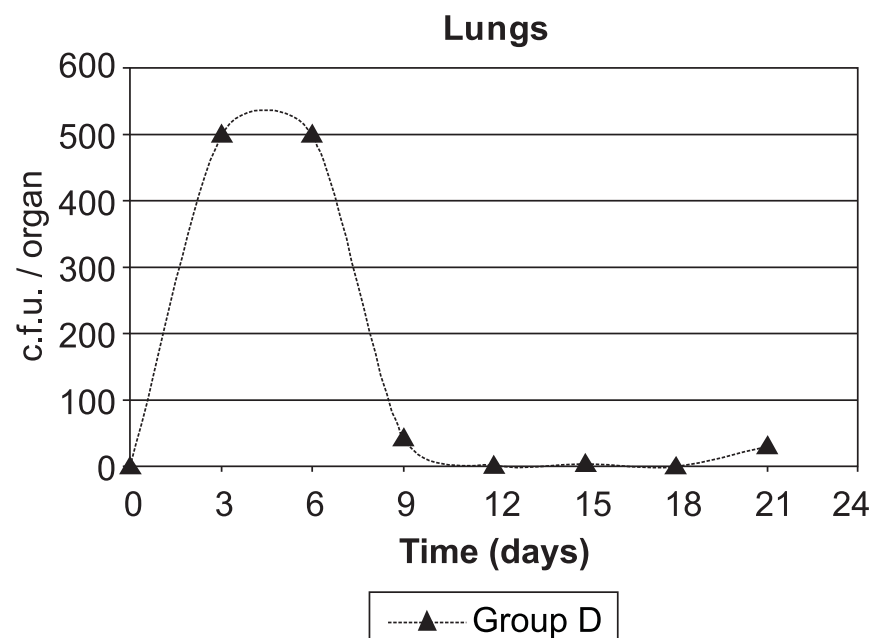

Figure 3. Variation in c.f.u. counts of $C$. albicans recovered from the lungs of swiss albino mice (M. musculus) over the period of experimental infection. 


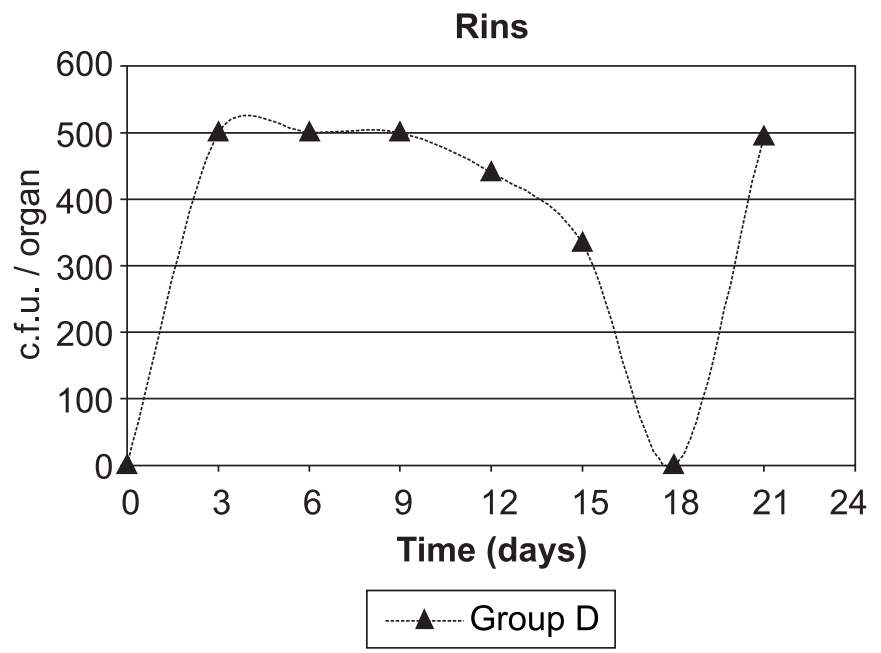

Figure 4. Variation in c.f.u. counts of $C$. albicans recovered from the kidneys of swiss albino mice (M. musculus) over the period of experimental infection.

\section{Histopathologic examination}

Lesions in the liver were observed only in the animals of groups C and D, which had been inoculated with strain 18 (immunosuppression negative and positive, respectively). In group C, only presence of focal inflammation was observed. Group D presented inflammatory reactions, including focal inflammation, inflammatory infiltration and abscesses constituted by polymorphonuclear neutrophils.

Interstitial pneumonitis was observed in the lungs in the animals of the 4 groups, but the infection was more severe and frequent in groups C and D. Masses of extravasal erythrocytes, areas of necrosis and infiltration of polymorphonuclear neutrophils and eosinophils have occurred.

Lesions in the kidneys in the form of inflammation, abscesses and necrosis were observed only in groups $\mathrm{C}$ and $\mathrm{D}$ (inoculated with strain 18). Yeasts presenting blastospores, pseudohypha and true hypha were observed only in this organ. In group $\mathrm{C}$, inflammatory infiltration and abscesses were found. Necrosis was not observed in none of the animals. In group D, inflammation, abscesses e necroses were observed.

\section{DISCUSSION}

The high number of c.f.u. isolated from groups B and D is possibly correlated with the number of cells of the inoculum and to the immunosuppression of these animals. Similar results were obtained by Holtschu et al. (7). These authors have observed $50 \%$ more positive cultures in immunosuppressed animals, specifically in liver, spleen and kidneys.

The groups A and B inoculated with the strain 743 presented less expressive results, either to positive cultures and c.f.u numbers or to the severity of the lesions. This fact might be related to the genetic instability of strains stored for a long period on mineral oil (14). Even though the storage have not decreased the ability of the strains to produce the enzyme in vitro (pathogenicity characteristic), the strain 743 was not fully virulent in vivo.

Some authors such as Chakrabarti et al. (3) and De Bernardis et al. (4) have indicated that it is not always possible to establish a correlation between the experimental pathogenicity with the proteinase activity in vitro. These authors reported that although some Candida isolates have been remarkably proteolitic, they were avirulent in experimental animals, mainly strains stocked in culture collections, suggesting that the period of laboratory storage is an important factor potentially able to induce loss of pathogenicity.

The SAPs (Secreted Aspartic Proteinases) of C. albicans are codified by, at least, ten different genes. This high number of similar genes might enhance the ability of the yeasts to secret a specific enzyme. The specific individual transcription of SAPs genes during the infection suggests that these genes might have specific functions during different phases of an infection. In fact, studies of inhibition and mutants disrupted of target genes have demonstrated that distinct SAPs (SAP1-3) are important during skin and mucosae infections, while others (SAP 4-6) are more relevant to systemic infections (16). The strain 18 might have activated distinct SAP genes when it reached systemic levels (experimental model), with an in vivo enzymatic production different of that determined in vitro. The in vitro enzymatic activity could have had decreased due to the antifungal drugs and anti-retroviral agents that the AIDS patient has taken and the virulence regained after the intraperitoneal challenge in the animals reaching systemic levels.

The high number of positive cultures from liver corroborates with Evans (5). According to this author, this organ is the less effective of the reticule endothelial system in destroying the microorganisms in both structures (pseudohypha and blastospores). However, because of its large extension when compared to other parenchymatous organs, the liver is more effective in clearing the yeasts from the bloodstream. In the present study, a severe infection was observed with multiple abscesses in the liver. These data are similar to the findings of Louria et al. (10) and Kuttin et al. (9). Some authors emphasise the importance of hepatic candidiasis in addition to renal candidosis (8).

Several authors indicate that the spleen is relatively important to the clearance of Candida cells from the bloodstream $(10,18)$. Group D was the only group in which the variation of c.f.u. counts over the period of infection was statistically significant, with a reduction of c.f.u. counts from the day 12. Similar data were obtained for liver. Although some authors reported focal and diffuse splenitis (10), lesions in the spleen were not observed in the present study. 
Regarding to the lungs, if the group D is evaluated, (the only group in which the variation of c.f.u. counts was statistically significant) it was observed an earlier reduction of c.f.u. counts, if compared to the other organs. These data agree with reports in the literature, which emphasize the efficiency of this organ to retain and eliminate viable structures of both Candida morphology (blastospores and pseudohypha) in models of experimental infection in vivo $(5,6,18)$. In the present study, a correlation between the variation of c.f.u counts over the period of infection and pneumonitis was not observed.

The kidneys are mentioned in the literature as the more affected organs in Candida models of infection and also in human disseminated candidiasis due to the ability of the yeast to produce pseudohypha in the tubular renal lumen and to penetrate in renal parenchyma. If the variation of c.f.u. counts during the infection is analysed, it is possible to observe that although there is a significant decrease after day 12 , the counts on day 21 (last day of experiment) are the same as on day 12 (p $<0.05$ ). These results stress the renal susceptibility to the yeast, which were extremely more severely affected than the other organs, being the only organs to present necrosis in the parenchyma of the animals of group D. There was no correlation between the variation of c.f.u. counts and the type of lesions during the model of experimental infection.

Several authors emphasize the severe invasions of kidneys by $C$. albicans, $C$. tropicalis and $C$. parapsilosis, where the histologic sections showed blastospores and pseudohypha in addition to a severe inflammation by polimorphonuclear neutrophils, abscesses, necrosis and variable degrees of hydronephrosis $(6,7,9,17)$.

In group $\mathrm{D}$, a positive culture of blood sample was obtained. This was the unique positive sample in all groups. The low number of positive blood cultures can be explained by the fact that the first sacrifice of the animals occurred after 3 days of inoculation. The literature mentions that yeasts are generally recovered from the blood only after a few hours of inoculation. This fact corroborates with the hypothesis of the efficiency of the parenchymatous organs to quickly remove $C$. albicans cells from the bloodstream $(6,17,18)$.

The fresh strain 18 was more virulent in vivo, as shown by the number of positive cultures and by the severity of the lesions observed at the histopathologic examination, despite the lower in vitro production of proteinase and phospholipase when compared to strain 743 , stocked for several years on mineral oil and presenting a higher enzymatic activity. Based on results of the present study, it is possible to infer that although C. albicans possesses various putative virulence factors, for instance the production of hydrolytic enzymes as an attribute to adhere to epithelial cells and consequently to invade the host, other factors may be involved for the success of this organism as a pathogen.

Host immunity is an important factor to modulate the status of $C$. albicans in the organism. As shown in the present study, the induction of immunosuppression made the animals more susceptible to the experimental infection. These results emphasize that further investigations on C. albicans virulence are necessary, since there is a noticeable increase in the number of immunocompromised patients and drug resistance.

\section{RESUMO}

\section{Modelo de infecção experimental em camundongos albino swiss (Mus musculus) sadios e imunossuprimidos utilizando cepas de Candida albicans com diferentes padrões de atividade enzimática}

Com o objetivo de avaliar a virulência de Candida albicans in vivo, foram selecionadas duas cepas de acordo com a atividade enzimática de fosfolipase e protease, para utilização em modelo de infecção experimental. Utilizou-se um isolado de secreção vaginal, estocado na Micoteca URM por 43 anos com alta atividade de fosfolipase $(\mathrm{Pz}=0.217)$ e de protease $\left(1.386 \mathrm{U} \cdot \mathrm{mL}^{-1}\right)$, e outro recém-isolado de secreção orofaríngea de paciente com AIDS, o qual apresentou baixa atividade de fosfolipase $(\mathrm{Pz}=0.482)$ e de protease $\left(0.780 \mathrm{U} \cdot \mathrm{mL}^{-1}\right)$. As amostras foram inoculadas por via intra-peritoneal em camundongos (Mus musculus) na presença e ausência de imunossupressão e a infecção foi avaliada durante 21 dias. A cada $72 \mathrm{~h}$ foram assepticamente removidos o fígado, baço, pulmões e rins e coletado o sangue desses animais. Foi quantificado o número de unidades formadoras de colônias (u.f.c.) recuperadas de cada órgão e realizada avaliação histopatológica dos mesmos. A cepa recém-isolada mostrou-se mais virulenta in vivo, quanto ao número de culturas positivas e à severidade das lesões observadas ao exame histopatológico. Não foi observada correlação entre a atividade enzimática in vitro e a virulência in vivo.

Palavras-chave: Candida albicans, enzimas extracelulares, virulência, infecção experimental

\section{REFERENCES}

1. Arango, G.A. Testes paramétricos. In: Bioestatística teórica e computacional. Guanabara Koogan, Rio de Janeiro, 2001.

2. Barnett, J.A.; Yamada, T.; Nozawa, Y. Yeasts: Characteristics and Identification. 4. ed. University Press, Cambridge, 1990, 1002p.

3. Chakrabarti, A.; Nayak, N.; Talwar, P. In vitro proteinase production by Candida species. Mycophatologia, 141:163-168, 1991.

4. De Bernardis, F.; Morelli, L.; Ceddia, T.; Lorenzeni, R.; Cassone, A. Experimental pathogenicity and acid proteinase secretion of vaginal isolates of Candida parapsilosis. J. Med. Vet. Mycol., 28:125-137, 1990.

5. Evans, Z.A. Tissue responses to the blastospores and hyphae of Candida albicans in the mouse. J. Med. Microbiol., 14:307-319, 1981.

6. Hasenclever, H.F.; Mitchel, W.O. Pathogenicity of $C$. albicans e $C$. tropicalis. Sabouraudia, 1:16-21, 1962.

7. Holzschu, D.L.; Chandler, F.W.; Ajello, L.; Ahearn, D.G. Evaluation of industrial yeasts for pathogenicity. Sabouraudia, 17:71-78, 1979. 
8. Khan, Z.U.; Misra, V.C.; Randhawa H.S.; Damodaran, V.N. Pathogenicity of some ordinarily harmless yeasts for cortisone treated mice. Sabouraudia, 18(1):319-327, 1980.

9. Kuttin, E.S.; Muller, J.; Douchet, C.; Vogt, A. Immunological and pathological observations with Candida albicans-infected animals. Sabouraudia, 21:185-194, 1983.

10. Louria, D.B.; Brayton, R.G.; Finkel, G. Studies on the pathogenesis of experimental Candida albicans infections in mice. Sabouraudia, 2:271-279, 1964 .

11. Neder, R.N. Microbiologia: Manual de Laboratório. Nobel, São Paulo, 1992, p.81, 88-90, 95-96, 98.

12. Oliveira, E.E.; Silva, S.C.; Soares, A.J.; Attux, C.; Cruvinel, B.; Silva, M.R.R. Toxinas killer e produção de enzimas por Candida albicans isoladas da mucosa bucal de pacientes com câncer. Rev. Bras. Med. Trop., 31:523-527, 1998.

13. Singh, P.; Ghosh, S.; Datta, A. Attenuation of virulence changes in morphology in Candida albicans by disruption of the N- acetylglucosamine catabolic patwway. Infect. Immun. Dec. 78987903, 2001.

14. Smith D.; Onions A.H.S. The preservation and maintenance of living fungi. $1^{a}$ ed., Commonwealth Mycological Institute, USA, 1983, 51p.

15. Staib, P.; Kretschmar, M.; Nichterlein, T.; Hof, H.; Morschhauer, J. Host versus in vitro signals and intra strain allelic differences in the expression of a Candida albicans virulence gene. Mol. Microbiol., 44(5):1351-1366, 2002.

16. Sther, F.; Kretschmar, M.; Schaller, M.; Schafer, W.; Hube, B. Extracellular hydrolytic enzymes and their relevance during Candida albicans infections. Mycoses, 43:17-21, 2000.

17. Togni, G.; Sanglard, D.; Monod, M. Acid proteinase secreted by Candida tropicalis: virulence in mice of proteinase negative mutant. J. Med. Vet. Mycol., 32:257-265, 1994.

18. Trnovec, T.; Sikl. D.; Zemanek, M.; Faberová, V.; Bezek, S.; Gajdosik, A.; Koprda, V. The distribution in mice of intravenously administered labelled Candida albicans. Sabouraudia, 16:299-306, 1978. 